\section{Growth of Container-grown Cork Oak Seedlings as Affected by Foliar and Soil Application of Paclobutrazol}

\author{
Marta Pardos, ${ }^{1}$ Rafael Calama, ${ }^{2}$ and Gregorio Montero ${ }^{2}$ \\ CIFOR-INIA, Ap. Correos 8.111, 28080-Madrid, Spain
}

\author{
José A. Pardos ${ }^{3}$ \\ Unit of Plant Anatomy, Physiology and Genetics. ETSI Montes, Universidad \\ Politécnica de Madrid, 28040- Madrid, Spain
}

Additional index words. container production, Cultar, nonlinear mixed model, plant growth regulator, Quercus suber

\begin{abstract}
Four concentrations of paclobutrazol(PBZ) and two application methods (foliar spray-soil drench) were tested on 3-month-old container-grown cork oak (Quercus suber L.) seedlings. Shoot height was affected by PBZ concentration and application technique. Time course of height was modelled by nonlinear mixed model analysis. Reduced shoot height was the result of shortened and fewer internodes. A 25 to $625 \mathrm{ppm}$ soil drench or 625 to $15,000 \mathrm{ppm}$ foliar spray controlled over vegetative growth, resulting in a reduction between $13 \%$ and $90 \%$ in plant size relative to untreated controls. Seedlings responded to soil drench at a lower PBZ concentration than for a foliar spray, but the danger of irreversible overdosing seems greater for a soil drench. Soil drench-and foliar spray to a lesser extent-also affected other shoot and root growth traits. PBZ dose decreased root volume and dry weights in a quadratic fashion with increasing dose, but decreased diameter and number of leaves linearly.
\end{abstract}

Paclobutrazol (PBZ) [(2RS, 3RS)-1-(4clorophenyl)-4,4-dimethyl-2- (1,2,4-triazol1-y1) pentan-3-o1)] is a potent triazole-type cytochrome $\mathrm{P}_{450}$ inhibitor that inhibits the biosynthesis of gibberellin while stimulating the accumulation of ABA (Marshall et al., $2000 \mathrm{~b}$ ). Through its mechanism of inhibition of gibberellin biosynthesis, but not as a sole effect (Marshall et al., 2000a), it reduces internode elongation and leaf size (Ruter and Martin, 1994) while it increases root to shoot dry weight ratio (Swietlik and Miller, 1983; Watson, 1996), root volume and dry weight (Hetherington and Jones, 1990), leaf specific weight (Rieger and Scalabrelli, 1990), and root collar calliper (Oliphant, 1991). PBZ has been extensively tested on horticultural species because of its ability to retard vegetative growth while increasing fruit set and yield (Rietveld, 1988). However, its use in forestry has been limited to the induction of flowering in broadleaved species, mainly in Eucalyptus (Griffin et al., 1993; Moncur and Hasan 1994), and for environmental adaptability in conifer seedlings ( Barnes and Kelley, 1992; Mahoney et al., 1998; Wheeler, 1987). The use of PBZ in cork oak (Quercus suber L.) has not been reported.

Cork oak has a special relevance in forestry

\footnotetext{
Received for publication 7 Apr. 2003. Accepted for publication 1 May 2005. This research was funded by INIA, project FO96-010-C2-1. We thank Ricardo Alía and Nikos Nanos for the revision of the manuscript. Mention of a trade name does not constitute a guarantee of the product by INIA

${ }^{1}$ Forest researcher. To whom reprints requests should be addressed; e-mail pardos@inia.es.

${ }^{2}$ Forest researcher.

${ }^{3}$ Professor.
}

and the rural economy of the Iberian Peninsula, pure stands cover $0.5 \times 10^{6}$ ha in Spain (Montero and Cañellas, 1999). This xerophytic species is widely used in the reforestation of former agricultural land, and $>100,000$ ha have been reforested between 1993 and 2003. The excessive shoot growth induced in seedlings by growth in nursery containers reduces survival after their transplantation in the field, mainly on xeric sites (Montero and Cañellas, 1999). This aspect of container-grown cork oak seedlings needs to be controlled.

The aim of this experiment was to investigate the time course of PBZ inhibition of height and PBZ activity on early growth and development of cork oak seedlings in the nursery. The specific objectives were to determine 1) the most effective application technique (by comparison of foliar vs. soil drench application of PBZ), and 2) the appropriate concentrations of $\mathrm{PBZ}$ required to reduce shoot growth without limiting root growth of cork oak seedling, when applied as a drench or foliar spray.

\section{Materials and Methods}

On 10 Dec. 1996, acorns of cork oak (Quercus suber L., provenance Parque de los Alcornocales-Serranía de Ronda, southern Spain) were sown in Sputnik 3-L pots (truncated square pyramid containers, $25 \mathrm{~cm}$ height, $169 \mathrm{~cm}^{2}$ and $64 \mathrm{~cm}^{2}$, upper and lower cross-sectional area, respectively), containing a medium of spaghnum peat moss and vermiculite $(3: 1$, $\mathrm{v}: \mathrm{v})$. Pots were placed in the greenhouse (30 ${ }^{\circ} \mathrm{C}$ day $/ 10{ }^{\circ} \mathrm{C}$ night temperature, under natural photoperiod, 450 to $600 \mu \mathrm{mol} \cdot \mathrm{m}^{-2} \cdot \mathrm{s}^{-1}$ of light intensity at midday, and watered to field capacity as needed) until 15 Apr. 1997, when seedlings were grown outdoors (lat. $40^{\circ} 25^{\prime} \mathrm{N}$, long. $3^{\circ} 44^{\prime} \mathrm{W}, 590$ melevation above sea level). Conditions outdoors from mid-April to midOctober were $18.9{ }^{\circ} \mathrm{C}$ average temperature (26.9 to $10.8{ }^{\circ} \mathrm{C}$ ), 1000 to $1500 \mu \mathrm{mol} \cdot \mathrm{m}^{-2} \cdot \mathrm{s}^{-1}$ of light intensity at midday, and $157.3 \mathrm{~mm}$ of rainfall and supplemental irrigation when needed (water added per week and pot $=15$ $\mathrm{L} \cdot \mathrm{m}^{-2}$ until mid-June, $30 \mathrm{~L} \cdot \mathrm{m}^{-2}$ between midJune and late July, $60 \mathrm{~L} \cdot \mathrm{m}^{-2}$ during August and $30 \mathrm{~L} \cdot \mathrm{m}^{-2}$ during September).

$\mathrm{PBZ}$ was used in the Cultar formulation (25\%, w/v, SC, SYNGENTA manufacturer), and all treatments were applied with a wetting agent, Tween $20\left(1 \mathrm{~mL} \cdot \mathrm{L}^{-1}\right)$ to the point of runoff. Application included foliar sprays (during which the PBZ did not enter the soil) and soil drench. PBZ at 0 (water control), 25, $625\left(25^{2}\right)$, and 15,625 (25 $) \mathrm{ppm} \mathrm{PBZ/pot}$ was applied in a volume of $5 \mathrm{ml}$ per pot, for the foliar spray; and as 100-ml liquid for soil drench. The specific doses of PBZ applied per plant were $0,0.13,3.1$, and $78 \mathrm{mg}$ of PBZ per spray, and 0, 2.5, 63, and $1562 \mathrm{mg}$ of PBZ per drench. Foliar sprays were applied uniformly to the shoots using a hand-held spray bottle, in three sequential sprays: 13 Feb. 1997 (day 0), 4 July 1997 (day 141), and 10 Sept. 1997 (day 204). Soil drench was applied to the pot medium surface as a single drench on 13 Feb. 1997 (day 0). Each sequential spray was less than one-third the dose of the single drench application, thus foliar application was repeated. Mean seedling height at the time of the first application (day 0) was $9.13 \mathrm{~cm}$ for the soil drench treatment and $8.35 \mathrm{~cm}$ for the foliar spray treatment. Mean height at day 0 was not significantly different between application techniques $(P>0.05)$. There were two between-units factors, namely, foliar spray and soil drench applications, in a four-concentration classification with 0 (water control), 25, 252, and $25^{3} \mathrm{ppm} \mathrm{PBZ/pot.} \mathrm{Fifteen} \mathrm{seedlings} \mathrm{were}$ randomly assigned to each of the eight treatment combinations (one seedling from control was removed from the analysis due to erratic growth). The within-units factor was time.

Shoot height from the soil surface to the swollen meristem of the leader branch was measured on days $0,16,34,83,119,162,204$, and 254. At the completion of the growing season (day 254) diameter at ground level of all seedlings were recorded. Components of shoot growth (mean internode length and number of internodes) were also measured.

The following parameters were determined after harvest, on 30 Oct. (day 254): leaf area (in $\mathrm{cm}^{2}$, with the use of an image analyser Delta-T), root volume (in $\mathrm{cm}^{3}$, by volumetric displacement of the root system), number of leaves and dry weight (leaves, shoot, root and plant, in g; seedling organs were oven dried to constant weight at $70{ }^{\circ} \mathrm{C}$ ). Shoot to root dry weight ratio was also computed.

Shootheight was analyzed by repeated measurements analysis of variance, RM ANOVA (Potvin et al., 1990). A Richards exponential equation (Eq. 1) was fitted to the data using a nonlinear mixed model (Lindström and Bates, 1990). Because application technique $\times$ PBZ concentration effect was significant, 
regression analyses were conducted separately for each application technique. Since at the application technique $\times$ PBZ concentration level, variability on the $b$ parameter among seedlings was small, $b$ was considered as a pure fixed parameter, while $a$ and $c$ were mixed parameters.

Height $(\mathrm{cm})=(a+u) \times\left(1-e^{-b \times t}\right)+(c+v) \times$ irrigation

Eq. [1]

where $t$ was days after treatment; $a, b, c$ were regression fitted coefficients ( $a$ represents the asymptote of height, $b$ corresponds to the slope of the curve, $c$ considered the unusual increase in shoot height between day 162 and day 204 due to an increase on irrigation regime to alleviate summer drought conditions); irrigation is a dummy variable, with value 1 if the observation was taken after irrigation effect and 0 in the contrary; $u$ and $v$ are random parameters, with mean 0 and bivariate normal distribution. Comparison among growth models was evaluated testing only the fixed parameters.

Separate statistical analyses were carried out to test the effect of soil drench and foliar application on shoot and root characteristics measured at harvest, because all doses tested for each application technique were not the same. A one-way ANOVA was used to determine the effect of PBZ concentration for each application technique. Significant differences were analysed by orthogonal test of contrast. A polynomial regression was calculated for concentration levels averaged over methods (Liyembani and Taylor, 1989). The control (concentration $=0$ ) was included in each regression. The model used to predict the response to the $i_{\text {th }}$ concentration is

$\mathrm{Y}_{\mathrm{ij}}=\mathrm{a}+\mathrm{b}_{1} \mathrm{X}_{\mathrm{i}}+\mathrm{b}_{2} \mathrm{X}_{\mathrm{i}}^{2}+\mathrm{b}_{3} \mathrm{X}_{\mathrm{i}}^{3}+\mathrm{e}_{\mathrm{ij}} \quad$ Eq. [2] where Yij is the observation corresponding to the variable $Y$ (shoot and root characteristics), $X_{i}=$ concentration of PBZ applied as soil drench or Ln (concentration of PBZ applied by spray +1 ) (log-transformed for normality), and $a$ is the mean response when no chemical was applied. The terms $b_{1}, b_{2}$ and $b_{3}$ are, respectively, the linear, quadratic, and cubic polynomial regression coefficients and $\mathrm{e}_{\mathrm{ij}}$ the random error term. When the mean square value describing the cubic or cubic and quadratic responses was not significant, the model was refitted with these coefficients set to zero. The analyses were done with the GLM procedure from the SAS system (SAS, 1998). The nonlinear model was fitted with the NLINMIX macro of SAS (Wolfinger, 1997).

\section{Results}

Height. Seedling height responded to PBZ treatment during the first $16 \mathrm{~d}$ after application in the PBZ sprayed seedlings and between day 16 and day 34 in the soil drench treated seedlings (Fig. 1). PBZ dose decreased shoot growth with increasing dose. Shoot elongation was almost completely inhibited by soil drench at $25^{2}$ and $25^{3}$ ppm PBZ after d34, whereas the $25 \mathrm{ppm}$ soil drench PBZ concentration reduced final shoot height by $40 \%$, compared to the control. The inhibition of shoot growth by foliar spray was not so marked. Final shoot height was reduced between $13 \%$ with 25 ppm and $59 \%$ with $25^{3} \mathrm{ppm}$, compared to the control (Fig. 1).

Results of the repeated measures ANOVA are shown in Table 1. Anonlinear mixed model was used to fit an independent curve to shoot growth data for each PBZ concentration and application technique. The multivariate tests for the within-units effects are also shown in Table 1. The significance of the interactions means that both the application technique and the PBZ concentration influenced in a different way to shoot growth patterns over time. The analysis of the fixed parameters obtained from the mixed model analysis showed that effect on shoot growth of the increase on irrigation regime during summer drought conditions (parameter $c$ ) decreased exponentially as PBZ concentration increased $\left(r^{2}=0.73\right.$ for the soil drench application, $r^{2}=0.61$ for the foliar spray application), and was not significant for $25^{3}$ ppm PBZ soil drench-treated seedlings.
The reduction in shoot height caused by PBZ was due to a reduction in both number and length of internodes (Table 2). By day 254, PBZ reduced number and length of internodes by $33 \%$ and $48 \%$, respectively, in soil drenchtreated seedlings, and by $24 \%$ and $34 \%$ in seedlings sprayed with PBZ, as compared to the control.

Root and shoot characteristics. All shoot and root parameters were significantly affected by PBZ concentration, for the soil drench application. Differences between PBZ concentrations in the sequential sprays were only shown in shoot and stem dry weights (Table 3 ) and shoot to root ratio $(P=0.0092)$.

Root collar diameter, root volume, and root dry weight decreased significantly with increasing soil drench PBZ concentration. As PBZ concentration increased, root collar diameter and number of leaves decreased linearly. Leaf area and shoot to root ratio was diminished with PBZ in a quadratic fashion, and the greatest reduction occurred with the highest concentration. Shoots of seedlings treated with the highest soil drench concentration assumed a rosette-like appearance.

Leaf dry weight decreased quadratically with increasing PBZ concentration applied as soil drench. Leaf dry weight was reduced by $52 \%$ at the highest rate of PBZ compared to the control. The trend response of stem and shoot dry weight was similar to that of leaves.

Increasing the concentration of PBZ applied as soil drench decreased root dry weight quadratically. The same was shown for root volume. Root dry weight and root volume were reduced by $67 \%$ and $60 \%$, respectively, at the highest concentration of PBZ compared to the control.

\section{Discussion}

The time course of shoot height on Quercus suber depending on PBZ concentration and application technique was predicted by the proposed model (Eq. 1). The coefficients,

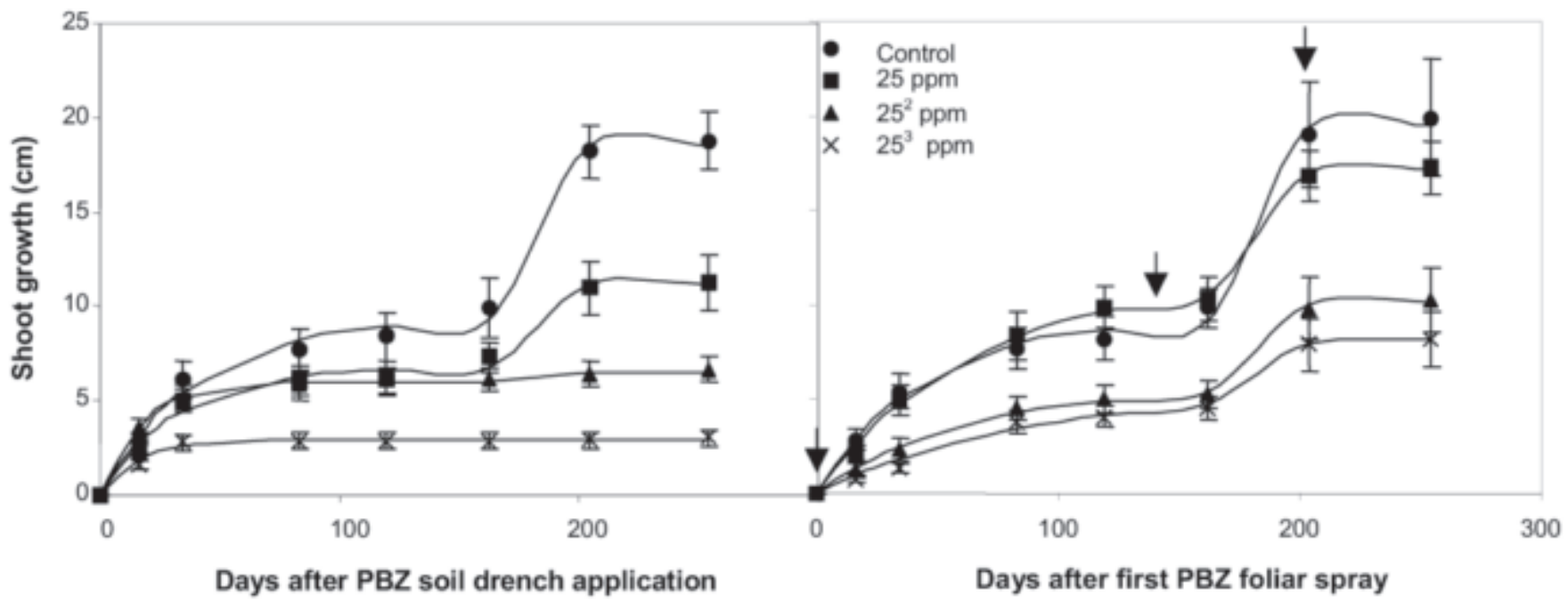

Fig. 1. Time course of cork oak seedlings shoot growth treated with 1) PBZ soil drench or 2) PBZ sequential foliar sprays. Each mean is comprised of 15 observations, except for control treatment in the foliar spray $(\mathrm{n}=14)$. Symbols indicate the mean, I bars indicate the standard error. Also shown are fitted curves with model equations from parameter estimates predicted by a nonlinear mixed model analysis. Growth $(\mathrm{cm})=a \times\left(1-e^{-b \times t}\right)+c \times$ irrigation. $\downarrow$ Sequential PBZ foliar sprays (day 0, day 141, day 204) 
relating the amount of growth regulator to shoot growth inhibition, varied among PBZ concentration and application technique. Even the effect of watering during the summer can be explained through the coefficient $c$. High PBZ concentrations cancelled the positive effect of irrigation in the soil drench, while it was only slightly attenuate in the foliar spraying. It is likely that at low PBZ concentrations the seedlings grow out of the effect of PBZ as they get larger.

The summer watering may have shortened the effect of PBZ by drainage of the retardant, but the effect persisted for the higher PBZ concentrations, mainly on the soil drench.

A common response of many seedlings to the application of $\mathrm{PBZ}$ is reduced shoot growth; however, the regulation of plant growth is affected by rate of application (Ruter and Martin, 1994) and application technique (Deneke and Keever, 1992). Shoot height data indicated that PBZ concentration reduced both the number and length of internodes. Webster and Quinlan (1986) reported similar results with plum trees. On the contrary, Grossmann (1990) in a review of plant growth retardants and Hetherington and Jones (1990) in Eucalyptus globulus reported the reductions in shoot growth were solely

Table 1. Results of the repeated measures ANOVA. Roy's greatest root statistic have been chosen for the multivariate tests for the within-units effects.

\begin{tabular}{lrc}
\hline Effect & F value & $P>\mathrm{F}$ \\
\hline Between subject & & \\
$\quad$ Application technique & 4.18 & 0.0432 \\
Paclobutrazol concentration & 29.46 & 0.0001 \\
Application technique $\times$ paclobutrazol concentration & 1.73 & 0.1644 \\
Within subject & & \\
Time & 83.56 & 0.0001 \\
Time $\times$ application technique & 6.48 & 0.0001 \\
Time $\times$ paclobutrazol concentration & 18.58 & 0.0001 \\
Time $\times$ application technique $\times$ paclobutrazol concentration & 2.51 & 0.0261 \\
\hline
\end{tabular}

because of a decrease in length of internodes, although according to Bausher and Yelenosky (1986) the effect on reduced internode length did not last long.

Increases in PBZ concentration depressed end-of-season height linearly, for both application techniques. Shoot elongation was almost completely inhibited by soil drench PBZ at $25^{3} \mathrm{ppm}$ after d34, final shoot height was reduced by $84 \%$, compared to the control, and root dry weight was also highly altered by $25^{3} \mathrm{PBZ}$. However, PBZ had phytotoxic symptoms, with apparent foliar chlorosis (5Y $7 / 10$, Münsel Table), when applied at $25^{3}$ ppm, soil drench. Erez (1986) also reported how high concentrations of PBZ can retard growth of peach seedlings in a too severe manner; even crinkled, small and distorted leaves can be produced, and dropped 3 months after application, as shown in Mussaenda cultivar (Protacio et al., 1997). At the lower end of the range, foliar PBZ at $25 \mathrm{ppm}$ were ineffective in altering shoot growth.

The seedlings were more responsive to soil drench PBZ application than to foliar spraying since the dose of PBZ in milligrams was higher in the soil drench for a PBZ concentration. Thus, the efficacy of the chemical

Table 2. The effect of paclobutrazol applied by soil drench or sequential foliar sprays on components of shoot growth (mean length and number of internodes) of cork oak seedlings, at the end of the experiment.

\begin{tabular}{|c|c|c|c|c|c|}
\hline \multirow{2}{*}{$\begin{array}{l}\text { Soil drench } \\
\text { concn (ppm) }\end{array}$} & \multicolumn{2}{|c|}{ Internode } & \multirow{2}{*}{$\begin{array}{l}\text { Foliar spray } \\
\text { concn (ppm) }\end{array}$} & \multicolumn{2}{|c|}{ Internode } \\
\hline & Length & No. & & Length & No. \\
\hline$\overline{0}$ & 0.61 & 30.70 & 0 & 0.71 & 32.85 \\
\hline 25 & 0.41 & 26.38 & 25 & 0.57 & 31.27 \\
\hline $25^{2}$ & 0.30 & 21.63 & $25^{2}$ & 0.43 & 25.50 \\
\hline $25^{3}$ & 0.24 & 13.60 & $25^{3}$ & 0.37 & 18.10 \\
\hline Significance & & & Significance & & \\
\hline P & $0.0001^{\text {**** }}$ & $0.0001^{\text {**** }}$ & $\mathrm{P}$ & $0.0001^{\text {**** }}$ & $0.0001^{* * * *}$ \\
\hline Control vs. rest & $0.0001^{* * * *}$ & $0.0001^{\text {*** }}$ & Control vs. rest & $0.0001^{* * * *}$ & $0.0001^{* * * *}$ \\
\hline 25 vs. $25^{2}$ and $25^{3}$ & $0.0001^{* * * *}$ & $0.0001^{\text {**** }}$ & 25 vs. $25^{2}$ and $25^{3}$ & $0.0021^{\text {*** }}$ & $0.0001^{\text {**** }}$ \\
\hline $25^{2}$ vs. $25^{3}$ & NS & $0.0010^{* * * *}$ & $25^{2}$ vs. $25^{3}$ & NS & $0.0022^{* *}$ \\
\hline
\end{tabular}

${ }^{2}$ Each soil drench mean is comprised of 15 observations.

${ }^{\mathrm{y}}$ Sequential sprays means are comprised of 15 observations, except control $(\mathrm{n}=14)$.

NS,,$* * * ; * * * *$ Nonsignificant or significant at $90 \%, 95 \%$, and $99 \%$, respectively.

Table 3. The effect of PBZ applied by soil drench or sequential foliar sprays on cork oak seedlings growth, at the end of the experiment.

\begin{tabular}{|c|c|c|c|c|c|c|c|c|c|}
\hline $\begin{array}{l}\text { Application } \\
\text { technique }\end{array}$ & Dose & $\begin{array}{l}\operatorname{Diam}^{2} \\
(\mathrm{~mm})\end{array}$ & $\begin{array}{l}\text { Root } \\
\text { vol }^{\mathrm{z}} \\
\left(\mathrm{cm}^{3}\right)\end{array}$ & $\begin{array}{l}\text { Leaf } \\
\text { area }^{z} \\
\left(\mathrm{~cm}^{2}\right)\end{array}$ & \multicolumn{4}{|c|}{ Dry $w^{2}(g)$} & $\begin{array}{c}\text { Leaves }^{z} \\
\text { (no.) }\end{array}$ \\
\hline \multirow{2}{*}{ Soil drench (ppm) } & 0 & 7.20 & 20.33 & 111.16 & 11.57 & 1.38 & 1.36 & 2.74 & 36.40 \\
\hline & $25^{3}$ & 4.97 & 8.13 & 53.14 & 3.84 & 0.59 & 0.45 & 1.05 & 14.07 \\
\hline \multirow[t]{2}{*}{ Significance } & Regression ${ }^{y}$ & $0.0377 \mathrm{~L}^{y}$ & $0.0039 \mathrm{Q}$ & $0.0044 \mathrm{Q}$ & $0.0039 \mathrm{Q}$ & $0.0057 \mathrm{Q}$ & $0.0267 \mathrm{Q}$ & $0.0106 \mathrm{Q}$ & $0.0490 \mathrm{~L}$ \\
\hline & Model $r^{2}$ & 0.47 & 0.67 & 0.43 & 0.73 & 0.53 & 0.55 & 0.311 & 0.4382 \\
\hline \multirow{2}{*}{ Test of contrast $\mathrm{t}^{\mathrm{x}}$} & 25 vs. $25^{2}$ and $25^{3}$ & $0.0106^{*}$ & $0.0094^{* *}$ & NS & $0.0011^{* *}$ & NS & NS & NS & $0.0189^{*}$ \\
\hline & $25^{2}$ vs. $25^{3}$ & $0.0453^{*}$ & $0.0009^{* * *}$ & $0.0015^{* *}$ & $0.0007^{* * *}$ & $0.0001^{* * *}$ & NS & $0.0154^{*}$ & NS \\
\hline \multirow[t]{5}{*}{ Foliar spray (ppm) } & 0 & & & & & & 1.56 & 3.08 & \\
\hline & 25 & & & & & & 1.07 & 2.38 & \\
\hline & $25^{2}$ & & & & & & 0.96 & 2.16 & \\
\hline & $25^{3}$ & & & & & & 0.85 & 2.05 & \\
\hline & Mean & $6.35^{\mathrm{x}}$ & 17.47 & 101.75 & 9.79 & 1.24 & & & 36.38 \\
\hline
\end{tabular}

${ }^{ }$Means comprised 15 observations, except for control treatment in the foliar spray $(\mathrm{n}=14)$.

${ }^{y}$ Linear $(\mathrm{L})$ or quadratic $(\mathrm{Q})$ fitted line responses across time.

${ }^{x}$ When PBZ concentration is not significant, only mean for application technique is shown.

${ }_{\mathrm{NS}, *, * * ; * * *}^{* *}$ Nonsignificant or significant at $90 \%, 95 \%$, and $99 \%$, respectively. 
increased with the volume applied, as noted by Gent (1997) for triazole growth retardants applied to Rhododendron and Kalmia. The PBZ concentration that caused a $50 \%$ inhibition on final shoot height was calculated to be between 25 and $25^{2}$ ppm for soil drench and between $25^{2}$ and $25^{3} \mathrm{ppm}$ for foliar spraying. Since the last spray had no effect on shoot growth, two sequential sprays were required to significantly retard shoot growth, and even then the efficacy of soil drench on final shoot height was 1.3- to 3-fold that of foliar spray, being more effective at lower concentrations. It is likely that the effects of PBZ on height decreased as application time was delayed. Similar results were reported by Sansavini et al. (1986) in 2-year-old apple seedlings, and by Hetherington and Jones (1990) in Eucalyptus globulus Labill.: sequential sprays were needed to avoid a resumption of growth which cancelled the previous retardation before the end of the season. Thus, the efficacy of the chemical increased with the soil drench application. It is likely that the more intensive response obtained with the soil drench was caused by increased wetting of solution onto the soil and by a more uniform distribution of PBZ activity (Million et al., 1999). Because PBZ is translocated acropetally in the shoots, via xylem (Reed et al., 1989), but also upwards in the roots, application to the soil (and thus, to the root zone) is likely to be more efficient than spray application to the leaves (Gent, 1997).

Although the primary effect of PBZ application was inhibition of stem growth, other growth parameters were also affected by PBZ, mainly when applied as soil drench. It appeared that root and stem dry weights were highly sensitive to alteration by PBZ. Since PBZ caused a general reduction in shoot biomass, it might be expected that a shift in resource allocation could bring about a general increase in root biomass (Early and Martin, 1988). However, both shoot and root biomass were reduced, similarly to results reported in American elm by Watson (2001) and in silver, red and hybrid maple by Marshall et al. (2000). It is not clear if the reduction of root growth after the soil drench application is a consequence of the direct exposition of the roots to high concentrations of $\mathrm{PBZ}$ or a result of the large reduction in shoot and leaf growth. The leaf area response to PBZ was similar to results reported in apple seedlings (Swietlik and Miller, 1983) and in Juniperus and Pyracantha (Ruter, 1994), among others. The response is not surprising, since gibberellins are essential hormones in leaf expansion (Liyembani and Taylor, 1989).

The effects of PBZ on cork oak seedling growth presented here are consistent with those reported on a wide variety of species. PBZ seems effective to control excessive shoot growth during nursery culture. The data indicate a more effective response of the soil drench application with a lower PBZ concentration, in comparison to the foliar spray. However, the danger of irreversibility overdosing with a soil drench seems greater. Thus, it appears that a PBZ concentration between 25 and $25^{2} \mathrm{ppm}$ for soil drench or between $25^{2}$ and $25^{3} \mathrm{ppm}$ for foliar spray will control over vegetative growth, without seriously affecting other growth parameters. However, to reduce application costs and improve effectiveness of PBZ, the soil drench seems more effective. Further work needs to focus on the amount of retardant that actually reaches the active sites in the plant and the persistence of PBZ along the time, mainly when seedlings are outplanted in the field.

\section{Literature cited}

Barnes, A.D. and W.D. Kelley. 1992. Effects of a triazole, uniconazol, on shoot elongation and root growth in loblolly pine. Can. J. For. Res. $22: 1-4$.

Bausher, M.G. and G. Yelenoski. 1986. Sensitivity of potted Citrus plants to top spray and soil applications of paclobutrazol. HortScience 21:141-143.

Deneke, C.F. and G.J. Keever. 1992. Comparison of application methods of paclobutrazol for height control of potted tulips. HortScience 27:1329.

Early, J.D. and G.C. Martin. 1988. Sensitivity of peach seedlings vegetative growth to paclobutrazol. J. Amer. Soc. Hort. Sci. 113:23-27.

Erez, A. 1986. Effect of soil-applied paclobutrazol in drip irrigated peach orchards. Acta Hort. 179:513-520.

Gent, M.P.N. 1997. Persistence of triazole growth retardants on stem elongation of Rhododendron and Kalmia. J. Plant Growth Regulat. 16:197-203.

Griffin, A.R., P. Whiteman, T. Rudge, I.P. Burgess, and M. Moncur. 1993. Effect of paclobutrazol on flower-bud production and vegetative growth in two species of Eucalyptus. Can. J. For. Res. 23:640-647.

Grossman, K. 1990. Plant growth retardants as tools in physiological research. Physiol. Plant. 78:640-648.

Hetherington, S. and K.M. Jones. 1990. Effectiveness of paclobutrazol in retarding height growth of Eucalyptus globulus seedlings. Can. J. For. Res. 20:1811-1813.

Lindström, M.J. and D.M. Bates. 1990. Nonlinear mixed effects for repeated measures data. Biometrics 46:673-687.

Liyembani, S. and B.H. Taylor. 1989. Growth and development of young peach trees as influenced by foliar sprays of paclobutrazol or XE-1019. HortScience 24:65-68.

Mahoney, S.R., S. Ghosh, D. Peirson, and E.B. Dumbroff. 1998. Paclobutrazol affects the resistance of black spruce to high light and thermal stress. Tree Physiol. 18:121-127.

Marshall, J., T. Beardmore, C.A. Whittle, B. Wang, R.G. Rutledge, and E. Blumwald. 2000. The effects of paclobutrazol, abscisic acid, and gibberellin on germination and early growth in silver, red, and hybrid maple. Can. J. For. Res. 30:557-565.

Marshall, J.G., R.G. Rutledge, E. Blumwald, and
E.B. Dumbroff. 2000. Reduction in turgid water volume in jack pine, white spruce and black spruce in response to drought and paclobutrazol. Tree Physiol. 20:701-707.

Million, J.B., J.E. Barrett, T.A. Nell, and D.G. Clark 1999. Paclobutrazol distribution following application to two media as determined by bioassay. HortScience 34:1099-1102.

Moncur, M.W. and O. Hasan. 1994. Floral induction in Eucalyptus nitens. Tree Physiol.14:13031312.

Montero, G. and I. Cañellas. 1999. Manual de reforestación y cultivo de alcornoque (Quercus suber L.). INIA, $\mathrm{M}^{\circ}$ de Agricultura, Pesca y Alimentación, Madrid, 1999.

Oliphant, C.1991. The use of paclobutrazol in the rooting medium of micropropagated plants. Comb. Proc. Intl. Plant Prop. Soc., p. 358-360.

Potvin, C., M.J.Lechowicz, and S. Tardif. 1990. The statisitical of ecophysiological response curves obtained from experiments involving repeated measures. Ecology 71:1389-1400.

Protacio, C.M., L.R. Obmerga, and S.V. Siar . 1997. Production of dwarf, compact plants of Mussaenda by paclobutrazol treatment. Philip. J. Crop Sci. 22:63.

Reed, A.N., E.A. Curry, and M.W. Williams. 1989. Translocation of triazole growth retardants in plant tissues. J. Amer. Soc. Hort. Sci. 114:893-898.

Rieger M. and G. Scalabrelli. 1990. Paclobutrazol, root growth, hydraulic conductivity and nutrient uptake of 'Nemaguard' peach. HortScience 25:95-98.

Rietveld, W. 1988. Effect of paclobutrazol on conifer seedlings morphology and field performance. Proc., Comb. Mtg. West. For. Nurs. Assn., Vernon, British Columbia, p. 19-23.

Ruter, J.M. 1994 Growth and landscape establishment of Pyracantha and Juniperus after application of paclobutrazol. HortScience 29:1318-1320.

Ruter, J.M. and C.A. Martin. 1994. Effects of contrasting climate and paclobutrazol on the growth and water use of two container-grown landscape plants. J. Environ. Hort.12:27-32.

Sansavini, S., R. Bonomo, A. Finotti, and U. Palara. 1986. Foliar and soil application of paclobutrazol on Gloster apple. Acta Hort.179:489-496.

SAS Institute, Inc. 1998. SAS/STAT user's guide, Version 6, Fourth Edition.

Swietlik, D. and S.S. Miller. 1983. The effect of paclobutrazol on growth and response to water stress of apple seedlings. J. Amer. Soc. Hort. Sci. 108:1076-1080.

Watson, G.W. 1996. Tree root system enhacement with paclobutrazol. J. Arboricult. 22:211-217.

Watson, G.W. 2001. Soil applied paclobutrazol affects root growth, shoot growth, and water potential of American elm seedlings. J. Environ. Hort. 19(3):1119-122.

Webster, A.D. and J.D. Quinlan. 1986. The influence of annual paclobutrazol treatments on the shoot growth, yield and fruit quality of Early Rivers sweet cherries, Acta Hort. 179:577-578.

Wheeler, N.C. 1987. Effect of paclobutrazol on douglas fir and loblolly pine. J. Hort. Sci. 62:101-106.

Wolfinger, R.D. 1997. Comment: experiences with the SAS macro NLINMIX. Statistics in medicine 16:1258-1259. 